\title{
Alsumas Considerações
}

(

$\mathrm{m}$ editorial no último número do ano sempre inclui algumas reflexões: análise do que foi realizado e do que ainda precisa ser feito. Estamos ativamente corrigindo todas as falhas, particularmente aquelas gentilmente apontadas em recente carta ao editor.

A RBR encerra 2003 abordando um tema controverso. Em função da preocupação da SBR e das comissões de estudo da artrite reumatóide e de epidemiologia, estamos submetendo uma proposta preliminar de conduta quanto à investigação de tuberculose em pacientes imunossuprimidos (particularmente para aqueles que são candidatos à terapia anti-TNF), fruto do trabalho de colegas infectologistas com larga experiência nesta área. De modo algum se pretende que as orientações sugeridas sejam absolutas ou definitivas. Objetivam apenas auxiliar o reumatologista em uma área controversa e constituir uma base de apoio para a prática clínica, e, só então, a partir da experiência em nosso meio, será possível definir um algoritmo válido.

A indexação no SciELO se mantém como nosso objetivo mais imediato e isto só é possível graças ao trabalho árduo, dedicação e altruísmo de todos, desde os editores até os envolvidos com o trabalho gráfico. Neste sentido, no próximo número introduziremos as últimas modificações necessárias para uma nova aplicação ao SciELO. Outros projetos serão iniciados em 2004, como participação no programa de educação continuada da SBR e AMB.

Iêda M. M. Laurindo Editora 